Доц. др Марина В. Кебара Универзитет у Крагујевцу

Филолошко-уметнички факултет

marina.kebara@gmail.com

\title{
УНУТРАШЊА ФОРМА РЕЧИ \\ И МЕТАЈЕЗИЧКА РЕФЛЕКСИЈА \\ У ФУНКЦИЈИ КОМУНИКАТИВНОГ ЧИНА \\ И ЈЕЗИЧКЕ ИГРЕ У ДЕЛИМА ПЕТРА КОЧИЋА
}

У раду истражујемо језичку игру у својству лингвокреативне делатности и метајезичке рефлексије, уз истовремено описивање поступака прекодирања (односно, преображаја у Бахтиновом тумачењу) смислова прецедентних феномена у уметничком дискурсу П. Кочића. Издвајајући три функције на којима се темељи прецедентност [ а) информативно-номинативна функција, б) вредноснооријентациона функција, в) атрактивна функција], вршимо (психо)лингвостилистичку (психопоетску) анализу неологизама у деривационим формама типа народне и дечје етимологије, који се јављају у својству прецедентних феномена у текстовима П. Кочића и основа су полифункционалности, као главног услова прецедентности.

Кључне речи: психолингвистика, језичка личност, језичка игра, метајезичка рефлексија, народна етимологија, прецедентни феномени.

1. Уводне напомене и теоријско-методолошко разматрање

Предмет нашег истраживања је прецедентни модел језичке игре у уметничком дискурсу, у поређењу са 
дечјим и народним/фолклорним дискурсом, а на корпусу уметничког стваралаштва Петра Кочића. У својству прецедентних феномена издвајамо деривационе форме типа gечје и народне ейимолоіије, који се уочавају у народном говору у облику деривационе активности, уз испољавање аспеката когнитивног и психолингвистичког с једне стране, и с друге, чисто језичког (лингвистичког) међуделовања у народном, односно, разговорном дискурсу: спонтане деривационе активности у моделу потенцијала који је језички нормиран. Говорне иновације анализираних типова могу да се одреде као мотиивациони моgификайори већ постојећих речи и то а) gеривациони и б) семанйички. Поменути модификатори укидају / преокрећу стереотипе аутоматизоване употребе језика карактеристичне за језичку свест (логичко-апстрактни модел мишљења) и језичку личност одраслих или образованих носилаца језика, попуњавајући лексичке лакуне узусног лексикона, уз истовремено испољавање својстава карактеристичних за модел мишљења детета и народног говорника (језик непосредности и чулности). На оваквој основи гради се њихова слика света (по Бахтину идеолошка позиција или социјални видокруг). Догађај општења путем метајезичких исказа, односно одступањем од норме ради појашњавања истине човекових међуодноса и слике света немогућ је ван речи у говору, што је сасвим у складу са Бахтиновим упоређивањем и довођењем у везу речи у животу и речи у поезији, односно уметничком изражавању уопште, те се у раду целокупно наше разматрање одвија кроз призму Бахтинове нове реторичке парадигме. Дечје и народне творевине у својству прецедентног феномена (прототекста или текста-донора) представљају плодну основу преосмишљавања и засићености текста новим смисловима, па као такве одликују се полифункционалношћу, 
тј. вршењем великог броја функција. ${ }^{1}$ У раду, издвајајући три функције на којима се темељи прецедентност, вршимо (психо)лингвостилистичку (психопоетску) анализу неологизама у стваралаштву П. Кочића, указујући на ток процеса семантизације путем метајезичке рефлексије и осмишљавања унутрашње форме речи, а у сврху остваривања уметничке функције језика и поетске употребе речи у уметничком дискурсу поменутог писца.

\section{1. Терминолошко одређење истраживаног проблема}

Појмови/термини језичка личносй, ирреиеgен $\bar{u}-$ ни феномени и нароgна етиимолоїија представљају оперативни апарат нашег методолошког поступка и главни оквир истраживања у овом раду.

1.1.1. Језичка личности (ЈЛ). - Поменути термин увео је у научни лексикон J. Н. Караулов (1987), иако се сматра да је његов прави аутор Г. И. Богин (Богин 1984). Структура језичке личности, коју је предложио Караулов, састоји се из три нивоа:

1) Вербално-семантички ниво за носиоца језика претпоставља нормално владање природним језиком, а за истраживача традиционалан опис формалних средстава изражавања одређених значења;

2) Когнитивни ниво, чије су јединице појмови, идеје, концепти, устројене у свакој језичкој индивидуалности у више или мање уређену и систематизовану слику света, одражава хијерархију вредности. Когнитивни ниво структуре ЈЛ и њена анализа подразумева експанзију (ширење) значења и освајање знања, што имплицира да

Вид. о томе шире у: Кебара 2014.

2 Г. И. Богин је установио и представио појам језичка личносй 1984. године у докторској дисертацији Моgель языковой личности в ее отночении к разновидностям текстов. 
обухвата интелектуалну сферу личности и пружа истраживачу могућност да путем језика и процеса говора и разумевања стигне до знања, свести и процеса људске спознаје.

3) Прагматични ниво укључује циљеве, мотиве, интересовања, усмереност, интенционалност. Овај ниво обезбеђује у анализи ЈЛ закономерни и последични прелазак са вредновања (процене) њене говорне делатности на осмишљавање реалне делатности (деловање у свету).

Први ниво већ одавно представља предмет научног изучавања, док су друга два постала објекат истраживања тек последњих деценија, што је условљено развојем психолингвистике, теорије вербалне комуникације, теорије говорних чинова и когнитивне лингвистике.

1.1.2. Прецеgенйни феномен (ПФ). - По Прохорову (Прохоров 2004), а у складу са Гудковим и Краснихом (Гудков, Красних 1997), поменути термин превасходно треба доводити у везу са различитим нивоима језичке личности. Прецедентност има четири нивоа, а сваки од нивоа карактерише се одређеним типом прецедентних феномена: 1) први ниво одговара језичкој личности као индивидуму и њеној личној (језичкој) свести, меморији и вокабулару - ауйойрецеgенйни феномени; 2) други ниво прецедентности карактерише ЈЛ као члана одређеног социјума и њена општа знања, представе (концепте, слике света), вредносне оријентације и средства њихове семиотизације са другим члановима датог социјума соиијумоирецеgенйни феномени; 3) трећи ниво прецедентности указује на формирање ЈЛ као члана одређеног национално-културног друштва у складу са њеним владањем општим системом културних предмета и симбола - национално-ирецеgенйни феномени; 4) последњи ниво прецедентности је најшири и указује на ЈЛ у корелацији са општељудским знањима и представама - уни- 
верзално-йрецеgенйни феномени (Прохоров 2004). Први тип прецедентних феномена користимо као критеријум одређивања, класификације и описа у нашој анализи индивидуалне језичке личности (конкретно ЈЛ јунака у текстовима Петра Кочића), док су преостала три критеријума релевантна за анализу колективне ЈЛ (колективне српске ЈЛ из које, природно, произилази напред наведена индивидуална ЈЛ). Наведени типови представљају у свести језичке личности одраз, односно рефлексију и концепте феномена из реалног света, битних за владање посебним сазнајним, емоционалним, аксиолошким значењима од стране дате ЈЛ и у корелацији су са посебним индивидуалним представама (аутопрецеденти) укљученим у непоновљиве асоцијативне низове или су у вези са представама (социјумопрецедентни феномени) познатим сваком просечном представнику одређеног социјума. У дечјој и народној језичкој свести и когнитивној бази социјумо-ПФ приближавају се аутопрецедентним, што је одговарајуће одражено у њиховом говорном/ језичком систему и сходно, стваралаштву и реторичкој парадигми.

1.1.3. Нароgна ейимолоїија. - Датим термином означава се читав низ појава почев од фонетских измена у речи (асимилација, дисимилација и сл.) до хомонимије (хомофоније) и паронимије. У Марузовом енциклопедијском речнику (Марузо 1960) наведени термин се тумачи као процес који се састоји у томе да се у свести говорника одређена реч испољава у корелацији са другим речима, које као да разјашњавају ову прву, док се у Розентаљевом приручнику (Розентаљ 2009) проналази тумачење по којем се термин народна ейимолоіија у најкраћем може одредити као прерада и преосмишљавање позајмљене или домаће речи према моделу блиске по звучању речи из матерњег језика, уз успостављање семантичких веза 
између њих на основу чисто спољашњег гласовног подударања и без уважавања стварних чињеница њиховог порекла. У основи овог процеса налази се дечја говорна парадигма и деривациона активност, базирана на преосмишљавању унутрашње форме речи (различитих морфемских компоненти) као поступка семантизације речи матерњег језика, непознатих дечјем носиоцу датог језичког система, што ову парадигму чини прецедентном за народног говорника, па сходно и уметничког ствараоца. Тако код деце налазимо: удобрити (са значењем постати добар), смехање од смејање, у народном говору полуклиника од поликлиника, а код Кочића, следствено томе:

палиграп (од параграф) [Кочић 1986: 131] велевлажни (од врлоуважени) [Кочић 1932: 170] лумера (од нумера, тј. број) [Кочић 1932: 167] укопација (од окупација) [Кочић 1932: 175] протокура (од протокол) [Кочић 1932: 186] позовка (од позив из суда) [Кочић 1986: 120] бевел (од нем. Beffel = заповест, наредба) [Кочић 1986: 118]

градијерати (од градирати, измерити граде, нпр. ракије) [Кочић 1986: 159]

уредован (који се односи на уред, канцеларијски) и сл. [Кочић 1986: 130]

\section{2. Истраживачки проблем и резултати анализе}

Полазећи од напред реченог, предмет нашег рада представаља језичка игра (ЈИ) као лингвокреативна делатност (Гридина 1996, 2006) уз описивање поступака прекодирања (односно, преображаја у Бахтиновом тумачењу) смислова прецедентних феномена или прецедентног модела ЈИ у уметничком дискурсу П. Кочића. 
Опирући се на учење В. В. Красних (Красних 1998), полазимо од поставке да се знања и представе чувају у свести у когнитивним структурама (КС), које представљају својеврсну садржајну (смисаону) форму кодирања и чувања информација (имају одређен садржај/ значење). КС формирају когнитивну базу (КБ), чије језгро чине прецедентни феномени (ПФ). Иза сваког ПФ истовремено стоји комплекс лингвистичких и феноменолошких структура (Кебара 2014), па као њихов производ

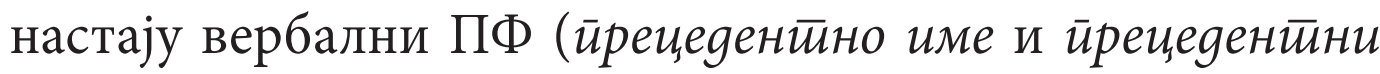

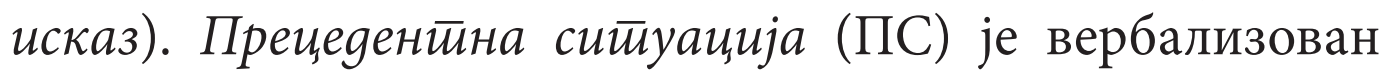
ПФ и представљена је у КБ у виду комплекса феноменолошких когнитивних структура, мада при актуализацији ПС у комуникацији делују лингвистичке когнитивне структуре. Прецеgенйни исказ (ПИС) представља чисто лингвистички феномен, обавезно и редовно продукован у говору, за разлику од других ПФ који могу да буду потенцијално фреквентни. Са аспекта форме ПИС може да буде изражен или текстом-извором (дечје пошалице, разбрајалице, ругалице, народни говорни изрази и сл.) или неком чисто језичком јединицом (синтагмом, реченицом, фразом) изграђеном по законима језика, али са добијеним статусом ПФ. Полифункционалност дечјих и народних творевина представља плодну основу преосмишљавања и засићености текста новим смисловима, те је као таква главни услов прецедентности.

У текстовима П. Кочића издвајамо и анализирамо три функције: a) информативно-номинативну функцију, б) вредносно-оријентациону функцију и в) атрактивну функцију. Критеријум на основу којег проводимо класификацију и описивање наведених функција у раду темељи се на феномену говорног доживљаја (и то на другом члану његових полова „ми-доживљају“) у Бахтиновом одређењу: 
„Doživljaj (ono što se izražava) i njegova spoljašnja objektivacija - sačinjeni su [...] od istog materijala. Nema doživljaja van znakovnog ovaploćenja. Prema tome, od samog se početka ne može ni govoriti o načelnoj kvalitativnoj razlici između unutrašnjeg i spoljašnjeg. Štaviše, središte organizovanja i formiranja doživljaja ne nalazi se unutra (tj. ne nalazi se u materijalu unutrašnjih znakova), nego napolju. Ne organizuje doživljaj izraz već obrnuto - izraz organizuje doživljaj, daje mu prvu formu i usmerava ga.“ (Бахтин 1980: 94) „U odnosu na potencijalnog (a ponekad i neposredno percipiranog) slušaoca mogu se razlikovati dva pola, dva ekstrema, između kojih se svest o doživljaju može sticati i [...] oblikovati, težeći čas prema jednom, čas prema drugom ekstremu“. [...] Mi-doživljaj nije nejasan, gregaran doživljaj: on je izdiferenciran, [...] porast svesnosti upravo je srazmeran čvrstini $i$ sigurnosti socijalne orijentacije (истакла М. К.)“ (Бахтин 1980: 97)

Издвојене функције дечјег и народног говора испољавају се као суштинске карактеристике у подлози језичке игре на основу којих она и може да се посматра и анализира као прецедент поетске употребе речи, конкретно у уметничком дискурсу П. Кочића.

\section{1. Информативно-номинативна функција}

Догађај општења путем метајезичких исказа, односно одступањем од норме ради појашњавања истине човекових међуодноса и слике света немогућ је ван речи, што је сасвим у складу са Бахтиновим упоређивањем и довођењем у везу речи у животу и речи у поезији, изнетом у његовом чланку Слово в жизни и слово в йоэзии (Веб 1), а исту мисао износи и у књизи: Марксизам и филозофија језика (Бахтин 1980). Бахтин

3 Чланак је потписао као В. Волошинов. 
је одступио од лингвистичке пардигме језика, ${ }^{4}$ показавши да је реч језика „полутуђа“ реч и да ће постати „своја“ тек у говору, у условима када је говорећи (језичка личност) испуни својом интенцијом, својом интонацијом, својом смисаоном и експресивном усмереношћу. Догађај може да буде описан само од стране самих учесника у њему (подвлачимо да учествовање у догађају представља нужан услов за игру, у том смислу и језичку игру). Оног тренутка када говорећи (језичка личност) помисли неки феномен или предмет, он одмах ступа у догађајни однос са њим, а истовремено и у међуоднос са самим сабеседником. Ова функција предмета/феномена представља његову стварну, потврђену вредност, односно, његов емоционално-вољни тон, који мора да буде одражен у речима, дакле и у говору који га изражава. Насупрот упрошћавању речи при њеном изучавању као речи уопште, изучавање у оквиру језичке игре у својству метајезичког контекста успоставља њену функционалну карактеристику као функције непрекидног стваралаштва човековог мишљења. Основна јединица говорне комуникације у дечјем и народном језичком систему, посматране у раду као прецедент поетске употребе речи, означена је као израз-исказ одређен реалним условима свог настанка, тачније, ситуацијом. Конкретна, посебна ситуација и она општа, шира социјална средина унутар које говорник егзистира (у раду је представљамо као вербализован ПФ - прецедентна ситуација, колективна

4 Ова парадигма се заснива на анализи или само речи (реч уопште, реч по себи) или само реченице (реченица уопште, реченица по себи). Вид. шире о томе у: Бахтин 1980.

5 Бахтинов термин іоворећи користи се у значењу „човек који говори“, односно, онај коме се говор јавља као урођено иманентно својство (Бахтин 1980) и, сходно томе, у форми је именице, те ћемо га и ми у даљем излагању користити у истој форми и значењу. 
слика света) одређују у целини структуру исказа и то изнутра: усмереност мишљења на потенцијални израз у корелацији са психо-социјалном усмереношћу, што упућује на спољашњост израза и унутрашњост доживљаја. Када непосредна ситуација формира исказ у складу са непосредним учесницима комуникације (исказивање у вези са датом ситуацијом) „настаје говорни мu-goīaђај који одређује оказионалну форму и стил исказа и као такав нала-

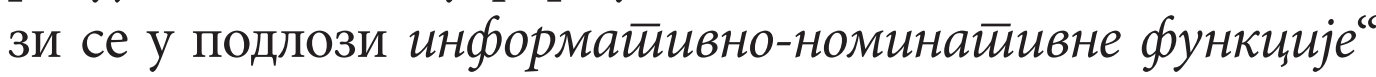
(Кебара 2014: 6). Наведену функцију можемо одредити као прецизирање или разјашњавање унутрашње форме речи путем њихове делимичне формалне модификације или корелације са разумљивим мотиватором, услед чега настају неологизми или оказионализми који образују номинативне низове паралелне узусу. У оваквом случају вертикала има предност у односу на хоризонталу (за разлику од треће, атрактивне функције). Напред речено јасно се уочава у примерима који следе (примере неологизама типа народне етимологије у Кочићевом тексту истакли смо болдирањем и подвлачењем):

Давиg: Добар дан, главати, царски господини!... (Кочић 1932: 166)

(именица глава и придев поглавити у функцији су мотиватора из којих је образован неолигизам главати)

Давиg: Тако ме славни суд пише и тако ми позовке шаље. (Кочић 1932: 167)

(синтагма судски позив као мотиватор за неологизам позовка)

Давиg: [...] у ту вашу школу, терезијанска што се зове, па кад та дјеца, мајчин сине, поприме вашу учевину... (Кочић 1932: 186) 
Давиg: О, имала зорли, кабасто учевна жена! (Кочић 1932: 197)

(глагол учити као мотиватор за неологизам у форми именице учевина и форми придева учевна)

Давиg: Баш ништа не знају? [...] А ко оно зна [...], осим тог царског чина на теби направити од аршина аршин и по̂, од оке по̂ке, а од по̂ке оку како кад, а?!! (Кочић 1932: 182)

(лексеме по̂/пола и ока као мотиватори за неологизам у форми сложенице пока)

Језичка личност (по Бахтину говорећи) принуђена је да се супротставља језику нивелисаном кроз норму како би изразила скривени смисао и омогућила стварање сопственог исказа. ${ }^{6}$ На оваквом становишту темељи се основно начело Бахтинове нове реторичке парадигме, будући да се творац језичке игре може посматрати као (мета)аутор-реторик. Говорни ми-gоживљај у описаним условима постаје говорни поступак-чин, који може да егзистира и да се остварује само тада када има о чему да се говори, он се рађа заједно са рађањем предмета говора, a рађа се из активног вољног односа, што значи да не представља ствар (у оном поимању како су реч тумачили формалисти), нити објекат-датост, већ задатост која захтева поступан развој у говору, у догађају говорне интеракције. Степен свесности, јасности и уобличено-

6 Изнета тврдња базира се на Бахтиновом замењивању Сосирове опозиције језик / іовор новом - исказ / језик, произашлом као резултат његове критичке анализе основних ставова два правца филозофско-лингвистичке

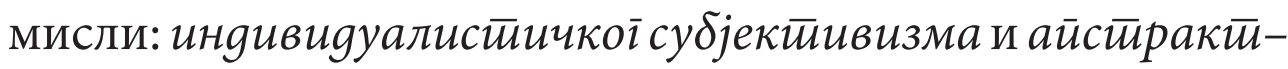
ної објекйивизма; Сосирово учење сврстао је у овај други правац (Бахтин 1980: 49-110). 
сти $\mathcal{M u - g o i ̄ a ђ а ј а ~ у ~ н а п р е д ~ н а в е д е н и м ~ и с к а з и м а ~ с а ~ о п и с а н о м ~}$ функцијом у подлози директно је пропорционалан (психо) социјалној усмерености. Спољашњи израз у корелацији је са правцем „унутрашњег говора“ (Бахтин 1980: 96) и у њему садржане интонације и смисла, чинећи их јаснијим, разумљивијим и стилски експресивнијим за сабеседника. Општа вредност добија стварни значај тек у индивидуалном контексту, што значи да је следећа етапа у процесу реторичког откривања прикључивање културних (колективних) вредности емоционално-вољном тону догађаја.

Језичко деловање информативно-номинативне функције темељи се на принципу метајезичке рефлексије, засноване на когнитивној обради рефлектованих језичких алгоритама путем одступања од конкретног творбеног (деривационог) модела. Погледајмо на примерима:

Нали-де, Мићане, једну чашу, па додај вамо. Ја ћу њу градијерати. Док окусим знам колико је гради. (Кочић 1986: 159)

(нормативно: градирати са значењем измерити степене/граде, нпр. ракије)

Како 'но кнеже? Реман, бе...

- Реглеман, чоче, па бевел, па с бевела на рапорт, а рапорт јавља на царство, царство на капетана, а капетан све даље до каплара. (Кочић 1986: 119-120)

(функцију мотиватора за указане неологизме врше позајмљенице: реман од реглеман = уредба, правилник о вршењу службе, одредба, пропис, пословник; бевел од нем. $\underline{\text { Beffel }=~ з а п о в е с т, ~ н а р е д б а) . ~}$

Као вијећник, или, како се Јуре радије звао „царски проницитељ“, био је вреднији и бистрији у својој служби и од самог десетара. (Кочић 1986: 220) 
Подвучени неологизам у овом примеру јавља се у функцији ПФ, односно прецедентног имена, које представља својеврстан сложен знак, при чијој се употреби у комуникацији не врши ослањање на сопствени денотат (референт), већ на скуп диференцијалних обележја датог ПИ, структуираног од више елемената са значењем једног појма (царски проницитељ = већник)

Тужио сам јазавца маличном суду (од именице мала, односно, нормираног махала, као мотиватора, нап. М. К.) што ми је сатро 'курузе, знаш, у 'ној њиви под Медењаком. (Кочић 1932: 167)

Давиg: Добар дан, велевлажни господини! А не би, вели, згорег било кад би у малом суду и једно и друго рек'о: „Добар дан, главати и велевлажни господини!“ и дод’о: „Слуга сам покорни!“ (Кочић 1932: 170)

Давиg (cjega): Чудновату праву, главати господине, траже газде. Не знам ти ни казати. То ти је некаква варица, нешто шарено, нешто буди Бог с нами! Траже од Земљане Владе да нам изволи да се више не зовемо само Србови к’о до Косова, већ српски, православни, школски, црквенски и атоно-то... Ову пошљедњу ријеч не могу изговорити, па уби ме!... [...] ато-но-то. О, тешке ријечи, крст јој љубим! Прије би сломио језик, него што би је изговорио... (Кочић 1932: 183)

Напред речено посебно јасно се види у ниже наведеним примерима, у којима ликови приповетке, учесници у дијалогу, сами дају мотиваторе сабеседнику (подвучени неболдирани примери у Кочићевом тексту) у сврху објашњавања употребљених неологизама: варанција, 
петљанција, главати, синтагма округли суд, ослањајући се тако на процес метајезичке рефлексије:

Доста је, Петрићу, било твоје варанције и петљанције!! [...]

- Ама, шта вам је људи? - зачудих се још више , јер осјетих да својим говором и држањем нишане на мене. - Шта сам вам ја скривио?! Каква је то моја, Дурате, варанција и петљанција?! Мало јасније, браћо, мало јасније!...

- Све је бистро и јасно. Знамо ми твој марифетпук и шеретлук, стаде Дурат махати према мени руком. (Кочић 1986: 242)

(лексеме марифетлук и шеретлук врше функцију мотиватора у процесу метајезичке рефлексије и разјашњавања унутрашње форме речи, а у сврху добијања нове речи са експресивнијим значењем)

Кад им ја приведо’ јазавца и привеза' колику је штету починио, рекоше ми да идем округлом суду. - Окружном суду - исправља га онако званично кнез. - Чекајте, кнеже - љути се Давид - да кажем! (Кочић 1986: 115)

Јест, јест, тако је: главати господин-пријестолниче! Знам ја, тако му се вели. Само ти кажи Шваби: главати господине! Па немај бриге.

- Биће то свакако, Ђуро, да се каже: поглавити господине!

- А-а! - вели Ђуро и показује на главу. Главати, главати! лава, мозак, памет! (Кочић 1986: 37)

Језичка игра са информативно-номинативном функцијом у основи заснива се на игрању смисловима и ства- 
рању новог на основу прецедентне ситуације, као вербализованог прецедентног феномена. Поменути феномен егзистира у когнитивној бази у својству утврђене структуре, омогућавајући испољавање ауторског личног односа и сопствене слике света. На тај начин је задовољена тежња говорећег, односно језичке личности, да осмисли и преосмисли колективно искуство, постојеће у народном (националном, матерњем) језику у виду прецедентних феномена и то како вербалних, тако и вербализованих.

\section{2. Вредносно-оријентациона функција}

Вредносно-оријентациона функција врло често се остварује истовремено са информативно-номинативном, при чему у овој првој долази до „свесног играња језичким каноном кроз форму говорне агресије - изругивања и исмевања другог у језичкој игри или неког прецедентног феномена“ (Кебара 2014: 8), конкретно: прецедентне ситуације страха, неслободе, ауторитета као вербализованих феномена, уз изазивање ефекта појачане експресивности у перцепцији одговарајућег поступка ЈИ. Идеја активности, динамичности, животности, која прожима целокупан Бахтинов опус, налази се у корелацији не само са субјектом (језичка личност у нашем тумачењу), извором те активности (прозвођачем-ствараоцем) него и са ситуацијом непоновљивог догађајног тренутка.

Говорни ми-gоживљајупоменутој функцији испољава вредносну (аксиолошку) усмереност, али и пораст степена свесности, „сразмерног организованости и диференцијацији колективне слике света, односно чвршћој структури когнитивне базе“ (Кебара 2014: 8). Овакво тумачење темељи се на основној Бахтиновој хипотези да je „iskaz socijalan“ (Бахтин 1980: 91), што значи да се сваки сегмент израза-исказа одређује реалним условима датог исказа, превасходно најближом социјалном ситуацијом. 
У наведеном становишту јасно се огледа значај и функција феномена језичке личности, и то како индивидуалне, тако и колективне (такође и основе за разматрање појаве језичке игре), будући да се исказ гради у организованој социјалној интеракцији најмање два субјекта унутар колектива (социјума), а уколико нема реалног субјекта (конкретног учесника у вербалној комуникацији), тада се он претпоставља у личности „normalnog predstavnika one socijalne grupe kojoj govornik pripada“ (Бахтин 1980: 94). Основну функцију речи у оваквом тумачењу представља њена усмереност на конкретног (никако на апстрактног) сабеседника, на то ко је (из које социјалне групе) тај сабеседник, као и на постојећу слику света (по Бахтину социјални вияокруі̄) ${ }^{7}$ утврђеној у језичкој свести и когнитивној бази датих језичких личности које учествују у комуникацији. Наведеним поступком за грађење језичке игре, са вредносно-оријентационом функцијом у подлози, изражава се интенција језичке личности према испољавању личне компетенције у реализацији језичких могућности. Ова форма лингвокреативног мишљења, заједно са претходном функцијом, погодна је као поступак за асоцијативну и алузивну прераду одређеног знања (прецедентних феномена) и уочавамо је у функцији прецедента у Кочићевом стилском поступку (упор. са примерима језичке игре у дечјим ругалицама, насталим по истим законима реторичке парадигме као и у малим фолклорним жанровима овог типа: Коља-моља йрика / Смаз'о краву и бика; О Иване, бароне, / метини йушку

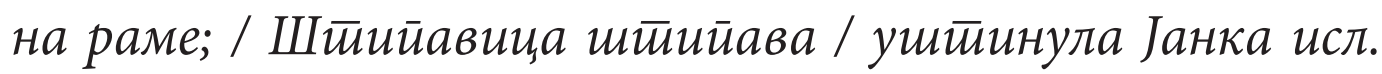
[Златна жица 1992: 115-117]):

7 У Бахтиновом поимању, „Socijalni vidokrug“ чине „socijalna grupa kojoj pripadamo, vreme u kojem živimo, takoreći savremenici naše književnosti, naše nauke, našeg morala, našeg prava.“ (Бахтин 1980: 95) 
- У име закона, не вриђај царске вире! - виче Јуре и дркће на ногама. У име царског пилиграпа! дере се Јуре, да сва брда одјекују.

Ова се свађа Микина и Јурина одма рашчу по селу, и од тог дана га је свак звао Lуре Пилиграп. (Кочић 1986: 224)

Надалеко су чувени Илица 'Одалица и Лазица Вуцалица. Па ко су они кад су тако разглашени? Илица 'Одалица и Лазица Вуцалица су пошљедњи тужни остаци многобројних сеоских трговчића-'одалица. (Кочић 1986: 245)

Давиg (ӣолаїано): Е, мој злоглави врнто и мој блентави ћићулајкане!... (Кочић 1932: 197)

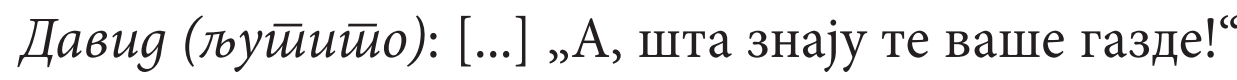
А шта ти знаш, вузле једно вузласто, осим тог царског чина на теби?! (Кочић 1932: 182)

Никола се забринуо. Шаље онако испред себе жене да „маме“ Тубу за Лазара. Ето, дошла Каласура (неки је зову Детикујом), па се распричала. (Кочић 1986: 128)

Други веле да су каури Ситвука на Бишићу заробили, па да су га одвели у Шибеник и залили оловом и рекли: „Досад си био сити вук, а сад буди гладни вук!...“ (Кочић 1986: 10)

Шути, ћићулајкане бож'и и бленто, злогло! - дере се кнез, а поблиједио као крпа у лицу. (Кочић 1986: 131)

Сви су дошли осим Чочорике и Злорека - јавља Jуре. Њи' два не признају ни закона, ни закона, ни пилиграпа, ни овог суда! (Кочић 1986: 228) 
Вредносно-оријентациона функција доводи до извесног преосмишљавања прецедентног имена (у овом случају се испољава као денотат првог реда) и давања новог смисла из којег настаје денотат другог реда, односно прецедентни исказ, чиме се постиже интезификација експресивности, актуализација лингвокреативног потенцијала, као и стилистички ефекат интезивнијег деловања на рецепијента, односно сабеседника.

\section{3. Атрактивна функција}

Атрактивна функција се базира на привлачењу саговорникове пажње, посебно поступком „антонимичне замене познатих речи, израза (вербални ПФ) или знања (вербализовани ПФ - прецедентни текст), међусобно повезаних или по аналогији или по контрасту“ (Кебара 2014: 9). Поступком антонимичне замене (често по принципу теза-антитеза) аутору-језичкој личности пружа се могућност да оствари нове стилистичке нијансе, чиме привлачи пажњу рецепијента (односно учесника комуникације, другог у ЈИ) необичношћу коришћења познатих речи, израза или знања (ПФ). То имплицира да је исказ још у процесу свог постајања изнутра у истој мери социјалан као и структура његове спољашње објективације. Стваралачка по себи игровна природа атрактивне функције као поступка-чина језичке личности најочигледније се испољава у ситуацијама кризне вербалне комуникације у којој се правила у извесној мери превазилазе. Наравно, овде се говори о животно-озбиљној игри, неопходној у условима најстрожије норме, која се опире на принцип карневалско-смеховне игре организоване по условно карневалским правилима. Као такав, поступак-чин се посматра у својству иманентног процеса, нарастања свести изнутра. Одступање у којем се испољава унутрашњи (по Бахтину, одговорни) поступак 
језичке личности иницира настајање кризне ситуације општења (Бахтин 2010) у социјуму и захтева од говорећег креативну језичку творевину, посебно усмерену на поменуту ситуацију. У оној мери у којој је колектив (колективна слика света у форми ПФ уграђених у структуру когнитивне базе) унутар којег се ЈЛ оријентише утемељенији, организованији и диференциранији, у тој мери је упечатљивији и сложенији унутрашњи свет аутора (ЈЛ) језичке игре, уз сразмеран пораст свесности, као и

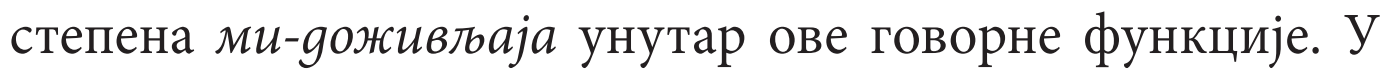
фолклорним творевинама срећемо говорне изразе типа: Газgа иразних јама. / По вазgуху рибу ловитии. / Преси-

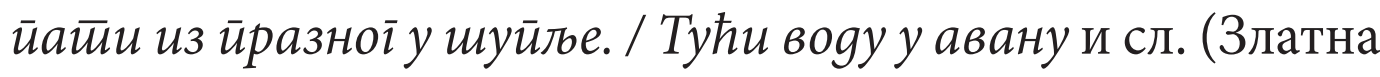
жица 1992: 11-23), који се темеље управо на атрактивној функцији и можемо их посматрати као вербалне прецедентне феномене (прецедентне исказе) у функцији текста-донора, односно денотата првог реда (прототекста). Овакви прототекстови већ постоје у когнитивној бази у својству прецедентног исказа, тј. лингвистичког феномена продукованог у говору и са добијеним статусом ПФ, постајући истовремено денотат другог реда за уметнички текст (овде хоризонтала има предност у односу на вертикалу):

Давиg: [...] Боже мој, Боже, чудне љепоте у вашег цара! Боже мој „Боже, ала ви усрећисте нашу земљу! Свијет се лијепо умртвио од неква добра и милине, па једва дише. Свак вес'о, задовољан, свак пјева, само се пјесма ниђе не чује. Једини сам ја (плаче) незадовољан, јадан и чемеран. (Кочић 1932: 170)

Давиg: О, ми смо задовољни! Притиснуло нас добро са свију страна; од некакве смо се милине умртвили, па једва дишемо. (Кочић 1932: 184) 
Давиg: [...] „О, да добре царевине, милостиви Боже!" занес’о се ја и лијепо јаукну' од некакве силне милине, а жена и дјеца од велике радости зајецаше. (Кочић 1932: 176)

Давиg: [...] Ја сам задовољан осудом. [...] Само још [...] ово додај: Давид Штрбац [...] захваљује се царевини, нашој премилостивој Земљаној Влади и славном суду, што су га од свега ослободили и, што 'но веле, к’о прст оголили. (Кочић 1932: 193)

Е мој брате, тешко нами! Ми смо ти једни, што се каже, незаробљени робови: код куће, а брез куће; код земље, а брез земље; код постојбине, а брез постојбине! (Кочић 1986: 65)

Нужан услов за остваривање напред реченог представља рейоричко ойкриће (изум), што и јесте један од основних постулата Бахтинове нове реторичке парадигме (Бахтин 2010) на који се позивамо и ослањамо у нашем истраживању и комплетној анализи. Атрактивна функција, као говорно-игровни поступак-чин у складу са Бахтиновом новом реторичком парадигмом (чији је стварни предмет човек који говори, односно активна језичка личност, а не апстрактна, изолована из контекста реч) усмерава исказ-израз на његово перципирање у форми јединственог догађаја са значењем конкретног контекста у који се истовремено смештају и чињеница и смисао.

\section{3. Закључне напомене}

Под прецедентним исказом, са прецедентним именом у основи, у предоченим и анализираним ситуацијама подразумева се репродуктиван производ говорномисаоне 
делатности, завршена и самодовољна јединица која може или не може да буде предикативна, поседујући посебан статус међу осталим прецедентним феноменима. Као такав, прецедентни исказ представља намерно уношење измена у исказ са циљем постизања одређеног ефекта (изражавање одређеног степена неког ми-догађаја). На тај начин одражава се стремљење језичке личности према осмишљавању прецедентних феномена, интезификацији експресивности, актуализацији лингвокреативног потенцијала. Путем експресије, као динамичне функције, у анализираним текстовима П. Кочића постиже се делотворност и активност, а реализује се помоћу разних видова прецедентних феномена, често у трансформисаном облику, чиме се постиже стилистички ефекат интезивнијег деловања на рецепијента (сабеседника, односно, другог учесника у игри). Ово је нарочито актуализовано у говорним и језичким творевинама са атрактивном функцијом, чији је крајњи циљ генерисање смисла.

Уметнички (поетски) текст уопште и текст П. Кочића посебно, посматран у односу на народну реторичку парадигму (жива реч у форми језичког догађаја, чина) и стваралаштво у својству прецедентног феномена, може имати два денотата: прототекст, односно извор, текст-донор (денотат првог реда) и прецедентни текст, односно текст-реципијент (денотат другог реда). Под прототекстом или текстом-донором подразумевамо текст који ствара основу за појаву прецедентног феномена, док као прецедентни текст или текст-реципијент означавамо народну реторичку парадигму рефлектовану у одређеној форми и садржају (то може бити неологизам, један, два или више стихова са значењем исказа и/или текста, и сл.) као општепознатој појави (аутопрецедентни, социјумопрецедентни, национално-прецедентни феномени) којој се прибегава у комуникацији или у уметничком дискурсу. Прототекст учествује у грађењу одређене експре- 
семе индиректно, тако што испуњава прецедентни текст својим садржајем, који је потом као резултат трансформације денотата другог реда одражен у датој експресивној или некој другој алузивној јединици. У том случају се денотат другог реда у односу на прототекст испољава као прецедентни текст (тј. текст-реципијент), прецедентна ситуација или прецедентни исказ.

\section{Извори}

Златна жица преко белог света, говорне народне умотворине. М. Клеут (прир.). Нови Сад: Светови, 1992

Кочић, Петар. Целокуина дела, кюига прва. Београд: Издавачко предузеће Народна просвета, 1932

Кочић, Петар. Приповијетке, къига I. Бањалука: Глас; Сарајево: Свјетлост, 1986

\section{Литература}

Bahtin, Mihail. Marksizam i filozofija jezika. Beograd: Nolit, 1980

Bahtin, Mihail. Ka filosofiji postupka. Beograd: Službeni glasnik, 2010

Богин Г. И. Модель языковой личности в ее отночении кразновидностям текстов: Автореф. дис. ... докт. филол. наук. - Л., 1984, доступно на http://www.dissercat.com/content/russkaya-yazykovaya-lichnost-v-aspektelingvokognitivnykh-stilei-reprodutsirovaniya-nauchnog.

Волошинов, В. Слово в жизни и слово в поезии. К вопросам соиитогической поэтики, Звезда, 1926, № 6, 244-267, доступно на http://crecleco.seriot.ch/textes/VOLOSHINOV-26/txt.html

Гридина, Т. А. Языковая игра: стереотип и творчество: монограбиия. Екатеринбург: Изд-во Урал. гос. пед. ун-та., 1996

Гридина, Т. А. Культурно-эстетические коды языковой игры в художественном тексте, Екатеринбург: ГОУ ВПО Урал, гос.пед. ун-т, 2006 
Гудков, Д. Б, В. В. Красных, И. В. Захаренко и Д. В. Багаева. „Некоторые особенности функционирования прецедентных высказываний“, Вестник МГУ. Серия 9. Филология. № 4. (1997): 106-118

Караулов, Ю. Н. Русский язык и языковая личность. Москва: Наука, 1987

Кебара, Марина. „Језичка игра у дечјем дискурсу као прецедент поетске употребе речи“. Кюижевности за gецу у науци и настиави, кю. 18, Зборник раgова са научноі скуйа одржа-

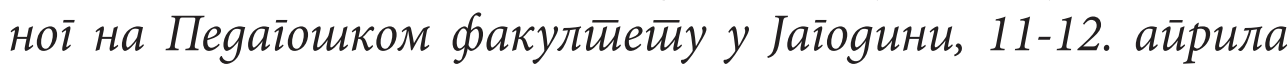
2014. іоoине. Виолета Јовановић и Тиодор Росић (ур.). Крагујевац: Универзитет у Крагујевцу, Педагошки факултет Јагодина, 2014. 109-125

Красних, В. В. Виртуальная реальность или реальная виртуальность (Человек. Сознание. Коммуникация). Москва: Диалог-МГУ, 1998

Марузо Ж. Словарь лингвистических терминов. Москва: Издательство иностранной литературы, 1960.

Прохоров, Ю.Е. Действительность. Текст. Дискурс. Москва: Флинта, Наука, 2004

Розентаљ, Д. Э, И. Б. Голуб, и М. А. Теленкова. Современный русский язык. Москва: АЙРИС-пресс, 2009 
Марина Кебара

\author{
ВНУТРЕННЯЯ ФОРМА СЛОВА \\ И МЕТАЯЗЫКОВАЯ РЕФЛЕКСИЯ \\ В ФУНКЦИИ КОММУНИКАТИВНОГО АКТА \\ И ЯЗЫКОВОЙ ИГРЫ \\ В ПРОИЗВЕДЕНИЯХ П. КОЧИЧА
}

\title{
Резюме
}

В данной работе мы исследуем языковую игру в качестве лингвокреативной деятельности и метаязыковой рефлексии, одновременно описывая приемы перекодирования (т.е. переобразования, в интерпретации Бахтина) смыслов прецедентных феноменов в художественном дискурсе Петра Кочича. Выделяя три функции, лежащие в основе прецедентности [ a) информативно-номинативная функция, б) ценностно-ориентирующая функция, в) аттрактивная функция], мы осуществляем (психо)лингво-стилистический (психопоэтический) анализ неологизмов в деривационной форме в виде народной и детской этимологии, выявляющих в качестве прецедентных феноменов в текстах П. Кочича и лежащих в основе полифункциональности, как главного условия прецедентности.

Ключевые слова: психолингвистика, языковая личность, языковая игра, метаязыковая рефлексия, народная этимология, феномены прецедента. 